\title{
Gold Complexes for Nonlinear Optics
}

\author{
Mark G Humphrey \\ Department of Chemistry, Australian National University, Canberra, ACT 0200, Australia \\ E-mail:Mark.Humphrey@anu.edu.au
}

Received: 30 June 2000

The nonlinear optical (NLO) properties of gold complexes are reviewed. Experimental procedures which have been used to determine NLO behaviour of gold complexes are summarized, structure / NLO property correlations are presented, and the potential of gold complexes for nonlinear optics is discussed.

New materials with desirable nonlinear optical (NLO) properties have been the subject of intense interest recently because these materials may provide an efficient means of modifying the nature of an incident light beam $(1,2)$. Materials with significant NLO properties may therefore be of technological importance for a variety of applications (optical processing, switching, frequency generation, data storage, optical communication, optical computing). Materials under investigation are incredibly diverse; they include organic and inorganic molecules, polymers, liquid crystals, inclusion complexes and composites. Amongst this array of materials are gold-containing compounds, the results from which are summarized in this review.

\section{NONLINEAR OPTICAL PROPERTIES}

A brief outline of NLO properties is presented here to clarify the subsequent discussion. At the molecular level, NLO responses can be attributed to changes in the electron polarization of the medium. Molecular polarization is described by the molecular dipole moment expansion,

$$
\mu=\mu_{0}+\alpha \mathrm{E}+\beta \mathrm{E}^{2}+\gamma \mathrm{E}^{3}+\ldots
$$

where $\mu_{0}$ is the intrinsic dipole moment of the molecule and $\mathrm{E}$ is the oscillating electric field strength. The coefficients $\alpha, \beta$ and $\gamma$ are the linear polarizability, and the first (quadratic) and second (cubic) hyperpolarizabilities (first-, second- and third-order molecular responses), respectively. This explanation is somewhat simplistic: The $\alpha, \beta$ and $\gamma$ terms are tensors, and the $\mu$ and $\mathrm{E}$ terms are vectors. The $\beta$ term is important for frequency mixing (eg second-harmonic generation, sum and difference frequency generation) and electro-optic applications (eg photorefractive applications such as real-time holography). The $\gamma$ term can be deconvoluted to real $\left(\gamma_{\text {real }}\right)$ and imaginary $\left(\gamma_{\text {imag }}\right)$ components, with the former corresponding to nonlinear refraction and the latter to nonlinear absorption. Nonlinear refraction is of significant interest for all-optical switching of signals, while nonlinear absorption is of interest in optical limiting (for example, the protection of sensors from high-energy laser pulses). Bulk material polarization can be described by a formula analogous to that given above for molecular properties,

$$
\mathrm{P}=\mathrm{P}_{0}+\chi^{(1)} \mathrm{E}+\chi^{(2)} \mathrm{E}^{2}+\chi^{(3)} \mathrm{E}^{3}+\ldots
$$

where $P_{0}$ is the intrinsic polarization of the material and $\chi^{(i)}$ are tensors of the same ranks as their corresponding molecular analogues. Several unit systems have been employed for the description of NLO properties. A summary of units and conversion factors for important properties can be found in reference (3). In the present review, comparisons are drawn between data within a particular Table, and all Tables contain data with one unit only, so a detailed understanding of conversion factors is not needed to draw structure-NLO activity correlations.

A two-level model, involving the ground state and a single charge-transfer excited state, has been developed to understand trends in $\beta$ for systematically varied organic molecules. Although it is no longer considered adequate, this model does reveal the structural features which are of importance for $\beta$ and it has been applied with some success to certain gold complexes. In this model,

$$
\beta \propto \frac{\mu_{\mathrm{ge}}^{2}\left(\mu_{\mathrm{ee}}-\mu_{\mathrm{gg}}\right)}{\mathrm{E}_{\mathrm{ge}}{ }^{2}}
$$

where $\mu_{\mathrm{ge}}$ is the transition moment, $\mu_{\mathrm{ee}}-\mu_{\mathrm{gg}}$ is the difference in dipole moments of the ground and excited states, and $\mathrm{E}_{\mathrm{ge}}$ is the difference in energy between the ground and excited states. Thus, complexes with an 
intense (large $\mu_{\mathrm{ge}}$ ) low energy (small $\mathrm{E}_{\mathrm{ge}}$ ) charge-transfer (large $\mu_{\mathrm{ee}}-\mu_{\mathrm{gg}}$ ) transition are expected to have significant $\beta$ values. Not surprisingly, dipolar complexes with a donor-bridge-acceptor composition have been the focus of most studies, but odd higher order multipoles may also contribute to $\beta$, so octopolar compounds have also been of interest (4).

\section{MEASUREMENT TECHNIQUES}

Many techniques have been developed to measure optical nonlinearities. For an excellent overview of these techniques, the reader is referred to reference (3), but it is appropriate here to briefly summarize procedures employed with gold-containing compounds. Molecular quadratic hyperpolarizabilities $\beta$ have been determined exclusively by hyper-Rayleigh scattering (HRS) and molecular cubic nonlinearities $\gamma$ by the $Z$-scan technique. Bulk quadratic susceptibilities $\chi^{(2)}$ have been ascertained by the Kurtz powder method, and bulk cubic susceptibilities $\chi^{(3)}$ by third-harmonic generation (THG). HRS involves detecting the incoherently scattered second-harmonic light generated from an isotropic solution of the compound. Because the second-harmonic component of the light scattered from the solution depends only on $\beta$ of the solute molecules, and it varies quadratically with the incident light intensity, varying the solute concentration allows $\beta^{2}$ to be determined. HRS is a relatively simple procedure, and permits the measurement of a range of materials, but it does require sensitive detection, it affords no information about the sign of $\beta$, and it can give unreliable results when the compound fluoresces at the second-harmonic frequency. Z-scan involves examining the self-focusing or self-defocusing phenomena of a nonlinear material. Z-scan is a fairly simple procedure which affords the sign and magnitude of the nonlinear refractive index, and gives the real and imaginary parts of $\gamma$, but it requires a high quality Gaussian beam and tells one nothing about the temporal behaviour of the nonlinear response. The Kurtz powder technique samples $\chi^{(2)}$, and involves directing a laser beam onto a solid microcrystalline sample and detecting the emitted second-harmonic light. This procedure can be used to rapidly screen the NLO activity of a range of compounds, but it has several shortcomings: noncentrosymmetric crystal packing is required, and the response depends on particle size (necessitating sieving of samples). The results from Kurtz studies have qualitative rather than quantitative significance.
THG involves measuring the third-harmonic light generated from a sample, from which $\chi^{(3)}$ can be obtained. This technique samples the electronic second hyperpolarizability (only nonresonant electron cloud distortion responds sufficiently rapidly to produce a third-harmonic response), but it is technically difficult: all materials exhibit THG, and allowances must be made to the observed response for contributions by cell windows, solvent, and even air.

\section{GOLD COMPLEXES FOR SECOND- ORDER NONLINEAR OPTICS}

All gold complexes for which the molecular second-order NLO properties have been measured are alkynyl complexes (Figure 1). The results of these studies are listed in Table 1.

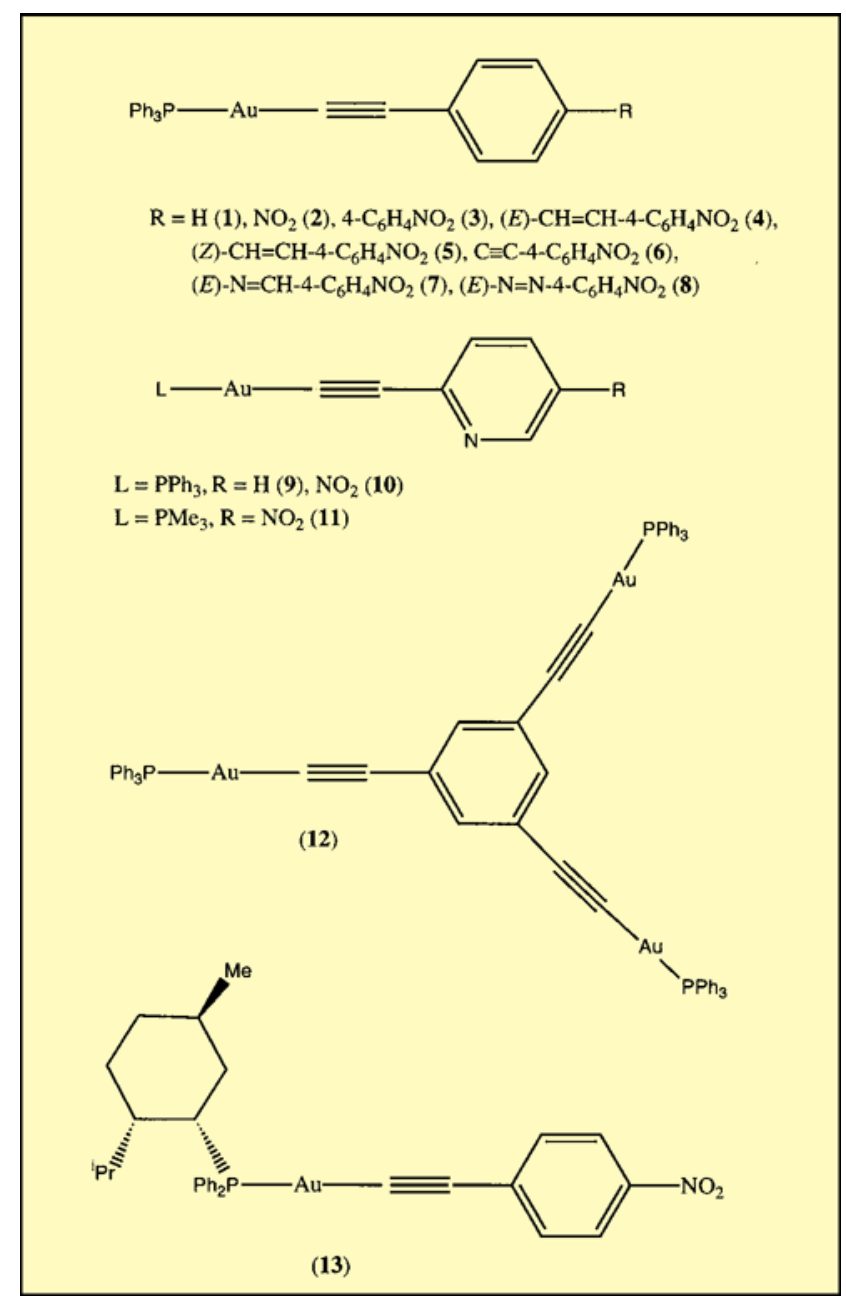

Figure 1 Structures for gold complexes with molecular secondorder NLO properties 
Table 1 Molecular Quadratic NLO Measurements for Dipolar Gold Complexes at $1064 \mathrm{~nm}$ by HRS in THF

\begin{tabular}{|c|c|c|c|c|c|}
\hline Complex & $\begin{array}{c}\beta_{\mathrm{zzz}} \\
\left(10^{-30} \text { esu) }\right.\end{array}$ & $\begin{array}{l}\lambda_{\max } \\
(\mathrm{nm})\end{array}$ & $\begin{array}{c}\epsilon \\
\left(10^{4} \mathrm{M}^{-1} \mathrm{~cm}^{-1}\right)\end{array}$ & $\begin{array}{c}\beta_{0} \\
\left(10^{-30} \text { esu }\right)\end{array}$ & Ref. \\
\hline $\mathrm{Au}(\mathrm{C} \equiv \mathrm{CPh})\left(\mathrm{PPh}_{3}\right)(\mathrm{I})$ & 6 & 296 & 1.3 & 4 & 5,6 \\
\hline $\mathrm{Au}\left(\mathrm{C} \equiv \mathrm{C}-4-\mathrm{C}_{6} \mathrm{H}_{4} \mathrm{NO}_{2}\right)\left(\mathrm{PPh}_{3}\right)(2)$ & 22 & 338 & 2.5 & 12 & $6-8$ \\
\hline $\mathrm{Au}\left(\mathrm{C} \equiv \mathrm{C}-4-\mathrm{C}_{6} \mathrm{H}_{4}-4-\mathrm{C}_{6} \mathrm{H}_{4} \mathrm{NO}_{2}\right)\left(\mathrm{PPh}_{3}\right)(3)$ & 39 & 350 & 2.9 & 20 & $6-8$ \\
\hline $\mathrm{Au}\left(\mathrm{C} \equiv \mathrm{C}-4-\mathrm{C}_{6} \mathrm{H}_{4}-(\mathrm{E})-\mathrm{CH}=\mathrm{CH}-4-\mathrm{C}_{6} \mathrm{H}_{4} \mathrm{NO}_{2}\right)\left(\mathrm{PPh}_{3}\right)(4)$ & 120 & 386 & 3.8 & 49 & $6-8$ \\
\hline $\mathrm{Au}\left(\mathrm{C} \equiv \mathrm{C}-4-\mathrm{C}_{6} \mathrm{H}_{4}-(\mathrm{Z})-\mathrm{CH}=\mathrm{CH}-4-\mathrm{C}_{6} \mathrm{H}_{4} \mathrm{NO}_{2}\right)\left(\mathrm{PPh}_{3}\right)(\mathbf{5})$ & $58^{\mathrm{a}}$ & 375 & 2.0 & $26^{\mathrm{a}}$ & $6-8$ \\
\hline $\mathrm{Au}\left(\mathrm{C} \equiv \mathrm{C}-4-\mathrm{C}_{6} \mathrm{H}_{4} \mathrm{C} \equiv \mathrm{C}-4-\mathrm{C}_{6} \mathrm{H}_{4} \mathrm{NO}_{2}\right)\left(\mathrm{PPh}_{3}\right)(6)$ & 59 & 362 & 3.6 & 28 & $6-8$ \\
\hline $\mathrm{Au}\left(\mathrm{C} \equiv \mathrm{C}-4-\mathrm{C}_{6} \mathrm{H}_{4}-(\mathrm{E})-\mathrm{N}=\mathrm{CH}-4-\mathrm{C}_{6} \mathrm{H}_{4} \mathrm{NO}_{2}\right)\left(\mathrm{PPh}_{3}\right)(\mathbf{7})$ & 85 & 392 & 2.1 & 34 & $6-8$ \\
\hline $\mathrm{Au}\left(\mathrm{C} \equiv \mathrm{C}-4-\mathrm{C}_{6} \mathrm{H}_{4}-(\mathrm{E})-\mathrm{N}=\mathrm{N}-4-\mathrm{C}_{6} \mathrm{H}_{4} \mathrm{NO}_{2}\right)\left(\mathrm{PPh}_{3}\right)(8)$ & 180 & 398 & 3.3 & 68 & 9 \\
\hline $\mathrm{Au}\left(\mathrm{C} \equiv \mathrm{C}-2-\mathrm{C}_{5} \mathrm{H}_{4} \mathrm{~N}\right)\left(\mathrm{PPh}_{3}\right)(9)$ & 7 & 300 & 2.1 & 4 & 10 \\
\hline $\mathrm{Au}\left(\mathrm{C} \equiv \mathrm{C}-2-\mathrm{C}_{5} \mathrm{H}_{3} \mathrm{~N}-5-\mathrm{NO}_{2}\right)\left(\mathrm{PPh}_{3}\right)(10)$ & 38 & 339 & 2.6 & 20 & 10 \\
\hline $\mathrm{Au}\left(\mathrm{C} \equiv \mathrm{C}-2-\mathrm{C}_{5} \mathrm{H}_{3} \mathrm{~N}-5-\mathrm{NO}_{2}\right)\left(\mathrm{PMe}_{3}\right)(\mathrm{II})$ & 12 & 340 & 1.6 & 6 & 10 \\
\hline I,3,5- $\mathrm{C}_{6} \mathrm{H}_{3}\left\{\mathrm{C} \equiv \mathrm{CAu}\left(\mathrm{PPh}_{3}\right)\right\}_{3}(\mathrm{I} 2)$ & $6 \mathrm{~b}$ & 298 & 6.9 & $4 b$ & 11 \\
\hline
\end{tabular}

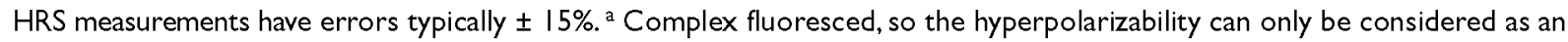
upper limit. ${ }^{b}$ Complex fluorescenced slightly, but the quadratic fit to HRS data suggests that this contribution is insignificant.

Structure-NLO activity trends observed with organic systems are also seen with these donor-bridge-acceptor alkynylgold complexes. Thus, introduction of strong acceptor group (progressing from $\mathbf{1}$ to $\mathbf{2}$, and from $\mathbf{9}$ to 10), bridge lengthening (progressing from 2 to $3-8$ ), modification of bridge stereochemistry (progressing from $Z$ to $E$, ie from $\mathbf{5}$ to $\mathbf{4}$ ), and modification of bridge (progressing from biphenyl $\mathbf{3}$ to tolane $\mathbf{6}$ to $E$-stilbenyl 4; progressing from imino-linked 7 to ene-linked 4 to azolinked 8) all result in an increase in observed and twolevel-corrected nonlinearity. Progressing from linear (1) to octopolar complex (12) does not lead to an increase in nonlinearity (complexes with a three-fold symmetry axis have octopolar symmetry). Ligand substitution (replacing $\mathrm{PMe}_{3}$ by $\mathrm{PPh}_{3}$ in progressing from 11 to 10 ) results in an increase in nonlinearity; the additional donor strength of the former is less important than the additional $\pi$ delocalization possibilities of the latter. Quadratic nonlinearities of these 14 valence electron (phosphine)gold alkynyl complexes are lower than those of analogous cyclopentadienylbis(phosphine)ruthenium or cyclopentadienyl(phosphine)nickel alkynyl complexes, which possess 18 valence electrons.

The bulk susceptibilities $\chi^{(2)}$ of nineteen gold complexes have been determined by the Kurtz powder technique at $1064 \mathrm{~nm}(10,12)$. Ten of these complexes decomposed with fluorescence in the laser beam, and a further eight complexes gave low $\left(<0.05 \mathrm{x}\right.$ urea) responses. For observable $\chi^{(2)}$, significant molecular nonlinearity combined with favourable molecular alignment is required: specifically, molecules must pack in non-centrosymmetric space groups, and molecular dipoles must align favourably. Incorporation of chiral ligands is one procedure to enforce noncentrosymmetric packing. One gold complex with a chiral ligand and a significant molecular dipole (13; Figure 1) is the only gold complex to have afforded a significant Kurtz powder response ( $2 \mathrm{x}$ urea).

\section{GOLD COMPLEXES FOR THIRD ORDER NONLINEAR OPTICS}

Gold complexes for which the molecular third-order NLO properties have been measured incorporate alkynyl ligands (Table 2) and S-ligands (Tables 3 and 4). These complexes are depicted in Figures 1 and 2.

Some of the $\gamma_{\text {real }}$ values of the alkynyl complexes in Table 2 are positive, and some of the $\gamma_{\text {imag }}$ values are significant, suggestive of two-photon states contributing to the observed responses. One must therefore be cautious when commenting on the effect of structural variation on refractive NLO merit. An increase in $\gamma_{\text {real }}$ is observed on introduction of the strongly electronwithdrawing (and therefore polarizing) $\mathrm{NO}_{2}$ group 


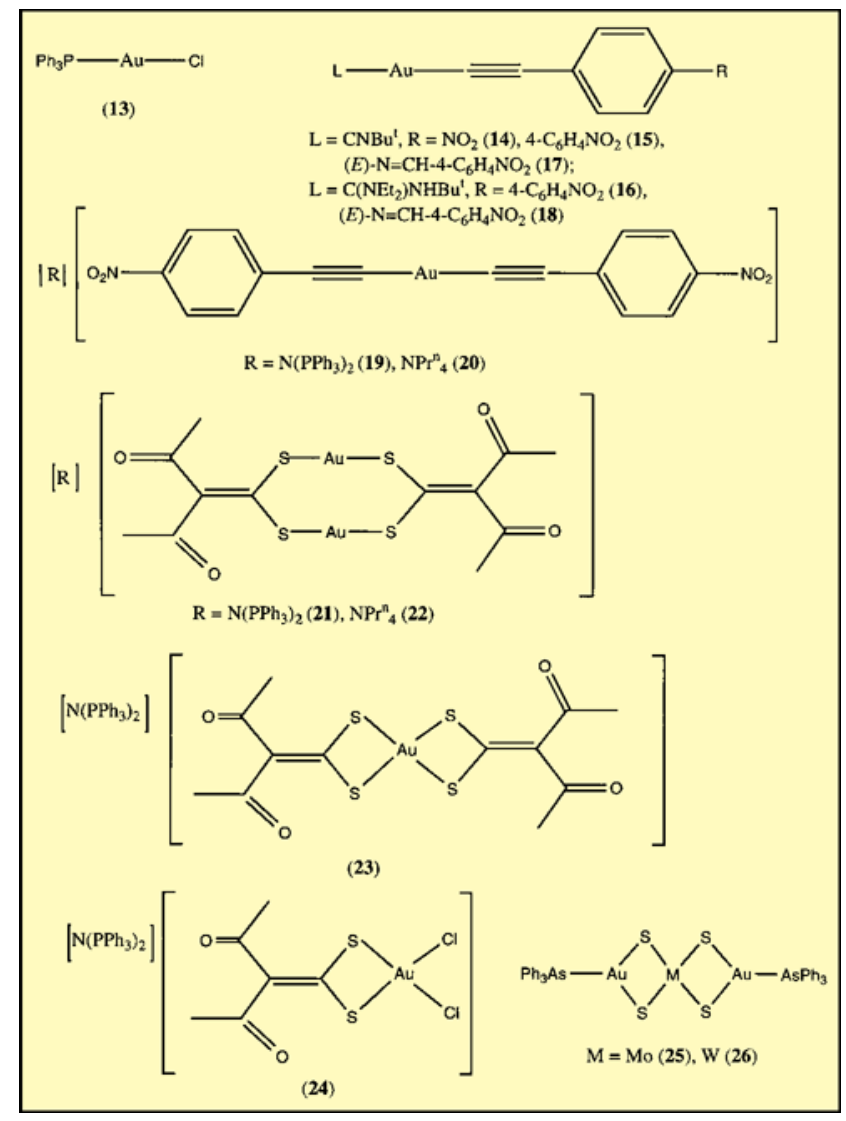

Figure 2 Structures for gold complexes with molecular third-order NLO properties

(proceeding from $\mathbf{1}$ to 2 ), $\pi$-system lengthening (extending the arylalkynyl $\pi$-bridge in proceeding from $\mathbf{2}$ to 3-6), and modification of bridge stereochemistry (replacing $Z-\mathrm{CH}=\mathrm{CH}$ by $E-\mathrm{CH}=\mathrm{CH}$ linking unit in proceeding from 5 to 4 ), structural changes which produce increases in $\gamma_{\text {real }}$ values in organic compounds. The large error margins preclude assessment of the effect of other structural modifications.

For the 1,1-dithiolene complexes summarized in Table 3, an increase in $\gamma_{\text {real }}$ is observed on replacing counter ion $\mathrm{NPr}_{4}+$ with PPN+ $\left[\mathrm{PPN}=\mathrm{N}\left(\mathrm{PPh}_{3}\right)_{2}\right]$ in proceeding from $\mathbf{2 1}$ to $\mathbf{2 2}$, proceeding from the mono1,1-dithiolene complex $\mathbf{2 4}$ to the bis-1,1-dithiolene complex 23, and introduction of a dimetallacycle containing two gold and four sulfur atoms (and concomitant short Au...Au interaction) in proceeding to 21 and 22. Au...Au bonding in the solid-state is a common motif, and this result suggests that attention should be focused on solid-state gold-containing materials, in which significant Au...Au interactions are often present, for third-order nonlinear optics, particularly those with infinite linear chain Au...Au...Au... interactions. The gold-containing clusters listed in Table 4 have extremely large $|\gamma|$ values, particularly as $\mathbf{2 6}$ is transparent at the fundamental frequency of the laser employed in these studies (measurements at frequencies close to absorption maxima can lead to resonance enhancement). However, unlike all other studies summarized in this section for which ps laser pulses were employed, the cluster studies utilized ns pulses, and contributions from, for example, excited state absorption cannot be discounted.

The cubic NLO merit of $\left[\mathrm{AuI}_{2}\right]$-containing thin films (Table 5) have also been assessed. The stearyl group was used to facilitate the preparation of thin films, and the resultant spin-coated films were treated with iodine. The third-order NLO properties are considerably enhanced by iodine-doping, which is proposed to arise from the formation of iodine bridges which enhance electron delocalization.

\section{CONCLUSION AND OUTLOOK}

Gold complexes are still largely unexplored as NLO materials. Results thus far have shown that the nonlinearities (both quadratic and cubic) of gold compounds can be significant, and gold compounds usually have better transparency characteristics than complexes of many other transition metals. The enhanced cubic nonlinearities observed with compounds containing gold...gold interactions, and in gold-containing clusters, are of particular interest. The studies to date have largely focused on developing structure-NLO property relationships of small gold-containing molecules. Before the true potential of gold complexes in NLO applications can be assessed, further studies need to be performed to address integration of gold compounds into processable polymeric materials, and assessment of the NLO properties of the resultant assemblies.

\section{ACKNOWLEDGEMENTS}

I wish to thank Professor André Persoons and his group (University of Leuven, Belgium; second-order NLO properties) and Dr Marek Samoc and Professor Barry Luther-Davies (Australian National University; Kurtz powder measurements and third-order NLO studies) for fruitful collaborations over the past few years, and members of my research group for their continuing synthetic and intellectual input. Financial support from the Australian Research Council and an ARC Australian Senior Research Fellowship are gratefully acknowledged. 
Table 2 Molecular Cubic NLO Measurements by Z-scan at 800 nm for Alkynylgold Complexes

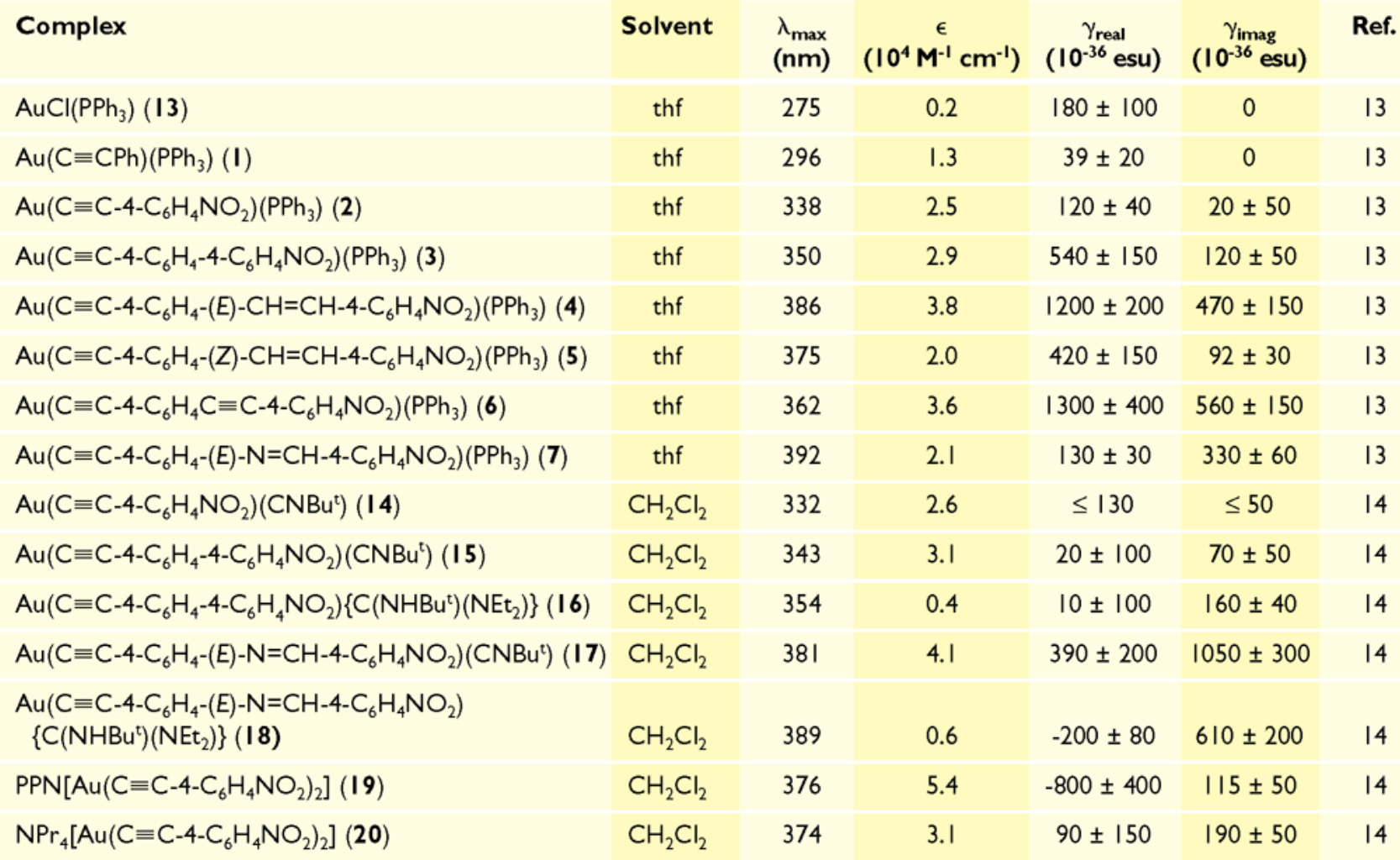

Table 3 Molecular Cubic NLO Measurements by Z-scan at $800 \mathrm{~nm}$ for Gold Complexes with S-Donor Ligands in $\mathrm{CH}_{2} \mathrm{Cl}_{2}$

\begin{tabular}{|c|c|c|c|c|c|}
\hline Complex & $\begin{array}{l}\lambda_{\max } \\
(\mathrm{nm})\end{array}$ & $\begin{array}{c}\epsilon \\
\left(10^{4} \mathrm{M}^{-1} \mathrm{~cm}^{-1}\right)\end{array}$ & $\begin{array}{c}\gamma_{\text {real }} \\
\left(10^{-36} \text { esu }\right)\end{array}$ & $\begin{array}{c}\gamma_{\text {imag }} \\
\left(10^{-36} \mathrm{esu}\right)\end{array}$ & Ref. \\
\hline$[P P N]_{2}\left[\mathrm{Au}_{2}\left\{\mu-\kappa^{2}-\mathrm{S}_{2} \mathrm{C}=\mathrm{C}\{\mathrm{C}(\mathrm{O}) \mathrm{Me}\}_{2}\right\}_{2}\right](2 \mathrm{I})$ & 393 & 3.0 & $215 \pm 20$ & $37 \pm 10$ & 15 \\
\hline$\left[N r^{n} 4\right]_{2}\left[\mathrm{Au}_{2}\left\{\mu-\kappa^{2}-\mathrm{S}_{2} \mathrm{C}=\mathrm{C}\{\mathrm{C}(\mathrm{O}) \mathrm{Me}\}_{2}\right\}_{2}\right](22)$ & 390 & 4.0 & $96 \pm 15$ & $44 \pm 10$ & 15 \\
\hline$[P P N]\left[A u\left\{\kappa^{2}-S_{2} C=C\{C(O) M e\}_{2}\right\}_{2}\right](23)$ & 356 & 6.8 & $88 \pm 15$ & $6 \pm 3$ & 15 \\
\hline$[P P N]\left[A u C I_{2}\left\{\kappa^{2}-S_{2} C=C\{C(O) M e\}_{2}\right\}\right](\mathbf{2 4})$ & 313 & 2.7 & $45 \pm 20$ & $3 \pm 2$ & 15 \\
\hline
\end{tabular}

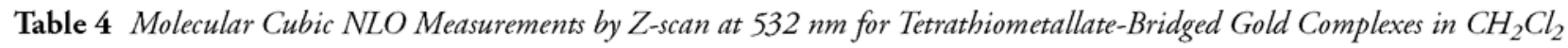

\begin{tabular}{|c|c|c|c|}
\hline Complex & $\lambda_{\max }(\mathrm{nm})$ & $|\gamma|\left(10^{-36}\right.$ esu $)$ & Ref. \\
\hline$\left(\mathrm{Ph}_{3} \mathrm{As}\right) \mathrm{Au}(\mu-\mathrm{S})_{2} \mathrm{Mo}(\mu-\mathrm{S})_{2} \mathrm{Au}\left(\mathrm{AsPh}_{3}\right)(25)$ & 500 & 30 & 16 \\
\hline$\left(\mathrm{Ph}_{3} \mathrm{As}\right) \mathrm{Au}(\mu-\mathrm{S})_{2} \mathrm{~W}(\mu-\mathrm{S})_{2} \mathrm{Au}\left(\mathrm{AsPh}_{3}\right)(\mathbf{2 6})$ & 410 & 65 & 16 \\
\hline
\end{tabular}

Table 5 Bulk Material Cubic NLO Measurements by THG Between 1.5 and 2.1 pm for [AuI $]^{-}$Containing Thin Films

$\begin{array}{llll}\text { Material } & \lambda_{\max }(\mathrm{nm}) & \chi^{(3)}\left(10^{-12} \text { esu }\right) & \text { Ref. } \\ \begin{array}{l}\text { ([stearyltrimethylammonium] } \\ \text { thin film }\end{array} & 298,364 & \leq 1 & 17 \\ \begin{array}{l}\text { [stearyltrimethylammonium] }]\left[\mathrm{AuI}_{2}\right] \text {-containing } \\ \quad \text { film, } \mathrm{I}_{2} \text {-doped }\end{array} & & \geq 10 & 17\end{array}$




\section{ABOUT THE AUTHOR}

Dr Mark Humphrey completed his PhD with Professor Michael Bruce at the University of Adelaide, Australia, in 1987. He then undertook postdoctoral research with Professor Gerhard Erker at the Universität Würzburg, Germany (1987-1989) and with Professor John Shapley at the University of Illinois, USA (1989-1990). He was appointed to a Lectureship in Chemistry at the University of New England, Australia, in 1990, moving to the Australian National University in 1994, where he is currently an ARC Australian Senior Research Fellow and Reader in the Department of Chemistry. He is the author of one hundred scientific papers, many dealing with the nonlinear optical properties of organometallic complexes.

\section{REFERENCES}

1 S.R. Marder, J.E. Sohn and G.D. Stucky (Eds), Materials for Nonlinear Optics: Chemical Perpectives, ACS Symposium Series 455, ACS, Washington DC, 1991

2 H.S. Nalwa and S. Miyata (Eds), Nonlinear Optics of Organic Molecules and Polymers, CRC Press, Boca Raton, Florida, 1997

3 R.L. Sutherland, Handbook of Nonlinear Optics, Marcel Dekker, New York, NY, 1996

4 J. Zyss, Nonlinear Opt., 1991, 1,3

5 S. Houbrechts, T. Wada, H. Sasabe, J.P.L. Morrall, I.R. Whittall, A.M. McDonagh,
M.G. Humphrey and A. Persoons, Nonlinear Opt., 1999, 22, 165

6 I.R. Whittall, M.G. Humphrey, A. Persoons and S. Houbrechts, Organometallics, 1996, 15,5738

7 S. Houbrechts, C. Boutton, K. Clays, A. Persoons, I.R. Whittall, R.H. Naulty, M.P. Cifuentes and M.G. Humphrey, J. Nonlinear Opt. Phys. Mater., 1998, 7, 113

8 S. Houbrechts, K. Clays, A. Persoons, V. Cadierno, M.P. Gamasa, J. Gimeno, I.R. Whittall and M.G. Humphrey, SPIE Proc, Int. Soc. Opt. Eng., 1996, 2852, 98

9 A.M. McDonagh, N.T. Lucas, M.P. Cifuentes, M.G. Humphrey, S. Houbrechts and A. Persoons, J. Organomet. 2000. 605, 193

10 R.H. Naulty, M.P. Cifuentes, M.G. Humphrey, S. Houbrechts, C. Boutton, A. Persoons, G.A. Heath, D.C.R. Hockless, B. Luther-Davies and M. Samoc, J. Chem. Soc., Dalton Trans, 1997, 4167

11 I.R. Whittall, M.G. Humphrey, S. Houbrechts, J. Maes, A. Persoons, S. Schmid and D.C.R. Hockless, J. Organomet Chem, 1997, 544, 277

12 I.R. Whittall, M.G. Humphrey, M. Samoc, B. Luther-Davies and D.C.R. Hockless, J. Organomet. Chem., 1997, 544, 189

13 I.R. Whittall, M.G. Humphrey, M. Samoc and B. Luther-Davies, Angewu. Chem., Int. Ed. Engh, 1997, 36, 370

14 J. Vicente, M.T. Chicote, M.D. Abrisqueta, P.G. Jones, M.G. Humphrey, M.P. Cifuentes, M. Samoc and B. Luther-Davies, Organometallics, 2000, 19, 2968

15 J. Vicente, M.-T. Chicote, P. González-Herrero, P.G. Jones, M.G. Humphrey, M.P. Cifuentes, M. Samoc and B. Luther-Davies, Inorg. Chem, 1999, 38, 5018

16 H. Zheng, W. Ji, M.L.K. Low, G. Sakane, T. Shibahara and X. Xin, J. Chem, Soc,, Dalton Trans, 1997, 2357

17 T. Kamata, T. Kawasaki, T. Kodzasa, H. Ushijima, H. Matsuda, F. Mizukami, Y. Nakao, Y. Fujii and Y. Usui, Synth. Met., 1999, 102, 1560
Continued from page 96

\section{REFERENCES}

1 AVT Report 4, Technologie des Drahtbondens, Germany, August 1991

2 'High Technology Bonding Tools', Gaiser Tool Company, Ventura, California, 1989

3 W. Kohl, The Interaction of Material and Machine Parameters in Thermosonic Bonding',translation of a reprint from 'Der Elekuroniker' Issue 6/1990, AT-Fachverlag, Stuttgart, Germany, 1991

4 Merkblatt DVS 2810 Drahtbonden, (instructional leaflet, wire bonding), Germany, 1992

5 S. Tomiyama and Y. Fukni, Gold Bull., 1982, 15 (2), 43

6 W. Kohl, 'Metallurgical Aspects of Wire Bonding', printed by Heraeus, 1990 ASTM-F72

Japanese Patent Application 5-179375 A

Japanese Patent Application 5-179376 A

10 T.H. Ramsey, Solid State Technology, 1973, Oct, 43-47

German Patent Application DE 3936281 A1

European Patent Application 0743679 A2

German Patent 1608161

US Patent 5491034

Japanese Patent 6-112251

European Patent 0288776

German Patent Application DE 19733954 A1

European Patent Application 0761831 A1

9 Japanese Patent Application 52-051867 A
20 T.B. Massalski, 'Binary Alloy Phase Diagrams', 2nd Ed., ASM International, Ohio, USA, 1990

21 Merkblatt DVS 2807 Teil 1, Zusatzwerkstoffe für Mikroverbindungen, Bonddrähte und Bändchen, (instructional leaflet, Addicion Materials for Microjoints, Bonding Wires and Ribbons), Germany, 1992

22 D. Ott and Ch. J. Raub, Gold Bull., 1981, 14 (2), 69

23 D.M. Jacobson, M.R Harrison, S.P.S. Sangha, Gold Bull, 1996, 29 (3), 95

24 G. Humpston and D.M. Jacobson, Gold Bull., 1992, 25 (4), 132

25 W. Kohl, S. Weber and A. Bischoff, Metallographic Investigation of the Au-Al Intermetallic Phase Formation, Metallography Conference of Deutsche Gesellschaft für Metallkunde, Garmisch-Partenkirchen, Germany, 1988

26 V. Koeninger and E. Fromm, 'Einflüsse von Alterung und Kontamination auf die Degradation von Gold-Aluminium-Ballbonds', (Influence of Ageing and Contamination on the Degradation of Gold-Aluminum Ball Bonds), Verbindungstechnik in der Elekronik und Feinwerktechnik, Düsseldorf, DVS-Verlag, 1996, 8 (4), 193

27 E.M. Philofsky, Solid-State Flectronics, 1970, 13, 1391

28 G. Majni and G. Ottaviani, J. Crystal Growth, 1979, 47, 583

29 P.K. Footner, B.P. Richards and R.B. Yates, Quality and Reliability Engineering International, 1987,3, 177

30 MIL-STD-883E

31 A. Russell, K Xu, S. Chumbley, J. Parks and J. Harringa, Gold Bull, 1998, 31, (3), 88

32 M. Judge, New Scientist, 1997, March 8th, pp 37

33 M. Poniatowski and M. Clasing, Gold Bull., 1972, 5 (2), 34

34 C.W. Corti, Gold Bull, 1999, 32 (2), 39 